\title{
Enduring the Autoimmune Aporia of Democratic Sovereignty
} Janar Mihkelsaar

Krisis 41 (1): 94-113.

\begin{abstract}
This article aims to read Rogues in order to argue that Derrida is neither an advocate of pure democracy nor a critic of sovereignty in general, but rather a thinker of democratic sovereignty that is based on articulating aporetic transactions between the exigency of the possible and what disrupts the order of the possible, i.e., the necessity of sovereign calculations and the exigency of a democratic "promise." Present-day politics illustrate the "autoimmune" collapse of aporetic transactions: neoliberals hypostasize an existing democracy and protect it against popular sovereignty, while populists hypostasize nation-state sovereignty and immunize it against the promise of "democracy to come."
\end{abstract}

\section{Keywords}

Aporia, Autoimmunity, Derrida, Democracy, Sovereignty.

DOI

$\underline{10.21827 / \text { krisis.41.1.37171 }}$

\section{Licence}

This work is licensed under a Creative Commons Attribution 4.0 International License (CC BY 4.0). (C) 2021 The author(s). 


\section{Krisis

\section{Autoimmune Aporia of Democratic Sovereignty}

Janar Mihkelsaar

\section{Introduction}

The present conjuncture is charged with the intensification of political struggle between rootless transnational elites and indigenous, local patriots, the enthusiasts of free trade and the supporters of economic protectionism, ardent liberals and vehement conservatives, liberal democrats and illiberal democrats. At the basis of this conflict are two incompatible sets of ideas: the one side professes to defend the rule of law, liberal institutions, international organizations and cooperation, individual liberties, and minority rights or, in a nutshell, the idea of modern democracy; and the counter-side claims to advocate decisiveness, national interests, political nationalism, economic protectionism, independent decision-making or, put simply, the idea of sovereignty. The principles of democracy, so it appears, are irreconcilable with that of sovereignty. From the historical perspective, there is nothing new in that, as early modern doctrines envisage sovereignty non-democratically, and the cracy or kratos (force, power) in demo-kratia has unerringly disturbed both practitioners and theoreticians of democracy from the Ancient Greek polis to the European Union. To shed light on our present predicament and to grasp the complex relationships of democracy and sovereignty, this article proposes to draw on the ideas of Jacques Derrida.

In the ever-expanding secondary literature on Derrida one can easily find excellent studies on the concept of sovereignty (e.g., Mansfield 2010) and that of democracy (e.g., Fritsch 2002; Haddad 2013), on the consideration of democracy without sovereignty (e.g., Caputo 2003), on the interpretative reconstructions of sovereignty without democracy (e.g., Agamben 1998), on the deconstructive elaboration of "sovereignty without sovereignty" (e.g., Nancy 2000), and on the conceptions of democracy and sovereignty (e.g., Thomson 2015). Needless to add, there are abundantly diffuse observations on the democracy-sovereignty interrelation (e.g., Thomson 2007). Wendy Brown, for instance, argues in her "Sovereign Hesitations" that Derrida reworks "the complex mutual dependence of democracy and sovereignty on ipseity" (Brown 2009, 119; original emphasis). Rather than focusing on ipseity (the circular identity of the 


\section{Krisis}

subject), I suggest rephrasing the reciprocal relationship of democracy and sovereignty in terms of what Derrida calls aporia (cf. Patton 2017).

To advance the case, I take my first cue from the following observation: "As always, these two principles, democracy and sovereignty, are at the same time, but also by turns, inseparable and in contradiction with one another" (Derrida 2005, 100; my emphasis). In the first section of this article, I explicate the sense in which the principles of sovereignty and that of democracy contradict one another and, on the other hand, the sense in which both principles are nonetheless inseparable. If my analysis of Derrida's argument that the principle of democracy contaminates and subverts that of sovereignty (and vice versa) is correct, however, it is clear that we should refrain from speaking in terms of principles, which implies "the princely and powerful authority of the first" (142; cf. Vardoulakis 2018, 83). Because of the mutual dependency of both concepts, the key question is not which principle wins out over the other and is more authoritative.

By focusing on Rogues: Two Essays on Reason (2005), the overall aim of this article is to argue that Derrida is neither an advocate of pure democracy nor a critic of sovereignty in general, but rather a thinker of what I call democratic sovereignty (Derrida 2005, 17). Keeping the overall objective of this article in mind, I argue in the second section that at the heart of democratic sovereignty are aporetic transactions or "negotiations" between the two heterogeneous and yet inseparable exigencies: the exigency of sovereign calculations and what disrupts the order of the possible (the exigency of the unconditioned or, in other words, of a democratic promise). In order to formulate, legalize, and institutionalize the singular appearance of promise, democracy has to rely on the sovereign art of the possible; and, conversely, the calculations of the sovereign power live off something that it is incapable of mastering and controlling. This something is the unconditioned, the "incalculable."

Drawing upon Derrida's idea of "autoimmunity" that is at play in the self-destruction of democracy and sovereignty, the fourth section aims to explicate the autoimmune process within democratic sovereignty by way of studying the socio-political logics of neoliberalism and right-wing populism $(35,45)$. In safeguarding an existing democracy against the supposed ills of political sovereignty, neoliberals actually betray nothing but democracy itself; or, conversely, in protecting vigorously the claim of national sovereignty, right-wing populists 


\section{Krisis}

actually undercut nothing but sovereignty itself. Regardless of numerous disagreements, the neoliberal and populist imaginations are similar in that both yield to the autoimmune selfbetrayal of democratic sovereignty. This very same autoimmune vulnerability, however, proves the untenability of pure democracy and a self-enclosed sovereignty.

The concluding section asks, against the backdrop of neoliberal populism, what it means to endure the aporia of democratic sovereignty. In order not to nullify the experience of aporia, I think, it is imperative according to Derrida to acknowledge that it is ubiquitously urgent to accept the exigency of aporetic negotiations, the unavoidability of risks, the element of "undecidability," the absence of a constituted subject (e.g., 150). What these features come down to accepting is that the aporetic limits of democratic sovereignty are not (re-)presentable, graspable, and masterable as such .

\section{Sovereignty and Democracy as Two Heterogeneous - and yet Inseparable - Principles}

In the ninth section of Rogues, “(No) More Rogue States," Derrida identifies sovereignty and democracy as two principles that organize the workings of the United Nations. Further on, Derrida adds, more generally: "As always, these two principles, democracy and sovereignty, are at the same time, but also by turns, inseparable and in contradiction with one another" (100; my emphasis). In this section, I first sketch some of the contradictory features of these two principles and then elucidate their reciprocal implications. Owing to the subversive relationship of sovereignty and democracy, I conclude that the question is not which principle is more primary.

The principle of modern democracy endorses the following set of ideas (100-101). In contrast to the equality according to quality (e.g., worth, merits), democracy advances the purely numerical equality in giving to each citizen one vote and counting it as one too. The democratic counting of votes determines the majority eligible to govern. Next, democracy discloses public space where "the difference between the public and the non-public remains an indecidable limit" to be determined again and again (92). Another characteristic feature is public debate in a plurality of platforms, where a discursive interaction between a wide range of participants and numerous topics is potentially endless, a back-and-forth of arguments (10). By engaging in a dialogue with one another, citizens come to share being-in-time and being-in-language, 


\section{Krisis}

and this kind of sharing generates meaning. This, in turn, is the condition of dividing and sharing the political, intellectual, and juridical power. Ideally, democracy encourages inclusive participation in civil society and political community. Last, but not least, the extension of voting rights and social and political rights to previously excluded segments of the population in the United Kingdom throughout the nineteenth and twentieth centuries illustrates the point that democratic values are universalizable.

Sovereignty dictates another set of ideas. Since early modern conceptualizations, beginning with Thomas Hobbes, sovereignty refers to the traits of unconditionality, indivisibility, and identity. Modern sovereignty is not dependent on tradition, hierarchical gradations, and even law, because the sovereign power has the right to suspend law, that is, to decide on the exception (154). Since sovereignty contracts into "the timeless instant of the exceptional decision," as Derrida claims, it lacks a "temporal and historical thickness" $(101,109)$. Furthermore, the sovereign "keeps quiet in the very ipseity," until the moment when it puts "an end in a single, indivisible stroke to the endless discussion" $(10,100)$. The moment of a decision concludes a democratic discussion, at least for the time being. With that, and other ways, an ultimate power imposes itself silently. This silence, however, is not the complete absence of discourse, but rather a kind of chatter that is unable to do justice to foreign idioms and claims of the "other" and, for that reason, lapses into a self-serving and self-centered monologue (101). As the power of the strongest asserts itself over the weak and the disadvantaged, it is always by definition abusive and illegitimate. In wanting to distinguish itself from a brute force, however, sovereignty needs to lay down the law and appeal to justice, all in order to legitimize itself (101).

In looking at the two sets of features, we are confronted with the following juxtaposition: sovereignty is associated with unconditionality, identity, indivisibility, decision, exceptionality, supratemporality, force, exclusivity, and finality, whereas democracy relates to dialogue, difference, temporality, sharing, inclusivity, universality, and openness.

Considered thus, the principal traits of democracy exclude that of sovereignty. It seems as though one needs to make a choice either in favor of a non-democratic sovereignty or of a nonsovereign democracy. But regardless of their contradictions, between democracy and sovereignty the relation is not only one of heterogeneity, but also one of a mutual contamination 


\section{Krisis}

and dependency. The crux of the matter, as I explain below, is that the two principles reciprocally implicate and, in so doing, reinforce one another (100).

Firstly, the workings of democracy harken back to the acts of sovereignty. As mentioned above, it is characteristic of democracy to include in public debates new, unheard, and unrepresented voices. But any deliberation calls forth an act, the function of which is to decide sovereignly upon fundamental issues such as: At what time does a deliberation come to an end? Exactly who has the right to participate? Who is entitled to speak at all? The similar necessity manifests itself in the mode of a political representation. For, on the one hand, as democracy supports the proliferation of social identities, the extension of rights to an even wider variety of individuals and groups, and the dividing and balancing of powers against each other, it yet, on the other, must harken back to the "supplement" of sovereignty in order to overcome the dispersion of socio-political, cultural, and ethnic identities and produce a collective, cohesive unity in order to concentrate power, govern itself, and reach a political decision (see Brown 2009, 118). Despite rightful suspicion and even hostility toward acts of power, democracy is inherently in need of sovereignty.

However, it looks as though this relationship is asymmetrical, because numerous forms of sovereignty from tyranny to monarchy reveal that no supreme power is by itself democratic. Sovereignty is in no particular need of democracy; moreover, it is also likely that sovereignty will abuse power and thus betray the ideals of democracy (Derrida 2005, 101; cf. Brown 2009, 120). On the other hand, the following is also true: sovereignty, when it exists, is in the process of undermining and refuting itself in a wide variety of ways, e.g., when it takes more time to reach a decision; when it is in spite of itself forced to engage with the "other"; when it runs up against divisions internal to itself; and when it has to reckon with the conditions of its exercise (Derrida 2005, 101, 109; cf. Patton 2017, 16-17). Temporality, divisions, and differences are the rudimentary elements of democracy. Of course, this is not meant to suggest that sovereignty necessitates democracy, or, even something more absurd, that sovereignty per se is democratic (as said, non-democratic powers throughout history prove the contrary), but rather to suggest that sovereignty is already infected from within by time, heteronomy, and difference. The nature and implications of this infection (or better auto-infection) come under scrutiny in the second and third sections. 


\section{Krisis}

Lastly, all the way through the development of deconstruction, from the beginning of the 1960s to his later works in the 1980s and 1990s, Derrida states that there is no "political or ethical turn" because the thinking of différance echoes a later thinking of "the political" or of "the democratic" that, I would say, consists neither in the avowing of democracy pure and simple nor the unrelenting critique of sovereignty pure and simple (Derrida 2005, 39). Rather, what is at stake in the democratic is the subversive interplay of democracy and sovereignty, and it is exactly because of this mutual interdependency that we should stop using the term "principle." As the discussion in the next section shows, the key question is not which principle comes first and establishes itself as a first authoritative principle, but that of discerning the heterogeneity and inseparability of two exigencies: the exigency of the unconditioned and that of the conditioned, the exigency of the incalculable and that of the calculable. The impossible passage from the one to the other is in my view what defines the aporia of democratic sovereignty.

\section{Aporetic Transactions at the Heart of Democratic Sovereignty}

The term "aporia" derives from the Ancient Greek word $\dot{\alpha} \pi \rho \rho i \alpha$, composed of the prefix $\dot{\alpha}-$ ("not," "without") and the word póros ("passage"). The prefix “ " $\alpha$," attached to póros, modifies the initial meaning of the word to the opposite, i.e., to a non-passage, to an absence of passage (Derrida 1993, 12). But the privative form $a$ of a-poros should not be taken purely negatively, since it "announces itself in an affirmative fashion" as the experience of aporia that couples the passage with the non-passage, the possible with the impossible, the conditioned with the unconditioned, the calculable with the incalculable (19). Relying on Derrida's account of aporias, the goal of this section is to argue that the aporia of democratic sovereignty consists in the juncture of the two heterogeneous and yet inseparable exigencies: "on the one side, the reasoned exigency of calculation or conditionality and, on the other, the intransigent, nonnegotiable exigency of unconditional incalculability," or, put differently, the exigency of sovereign calculations and the exigency of a democratic "promise" (Derrida 2005, 150).

With the decapitation of Louis XVI in 1793, the French Revolution replaced the absolute monarchy with the First Republic, monarchic sovereignty with popular sovereignty. In reading the first sections of Rogues, it seems as though the birth of democratic sovereignty produces nothing but the up-to-date addition to the historical succession of absolute powers. Democratic revolutions do not lead to a clean break with the traditions of political theology, which, 


\section{Krisis}

according to Derrida, is predicated on "some 'I can,' or at least the power that gives itself its own law, its force of law, its self-representation, the sovereign and reappropriating gathering of self in the simultaneity of an assemblage or assemble, being together, or 'living together"' (11; see also 13, 17, 24). Like the preceding forms of a supreme power, the sovereign self of the people consists in the ability to turn back on itself and postulate the full transparency of identity between, e.g., represented and representer, governed and governing. In relating to itself or signifying itself in such a manner, the people shapes itself in accordance with the image of god as "the origin and the conclusion, the cause and the end or aim, the driving cause and the final cause" (13).

As modern history has proven, the entrance of the people onto the stage of political history has indeed led to the absolutization of the infrastructures of political theology. The radicalization of features like "unconditionality," "indivisibility," "identity," and "unity" expresses itself in the efforts to erase completely any difference between the people and itself. A striving toward the unification and homogenization of a social body has resulted in extremes such as genocidal racism and Nazism. What such extremes like these unveil is the "phantasmatic" trait of sovereignty to auto-posit itself "as immortal and indivisible precisely because it is mortal and divisible," as self-identical and unconditional precisely because it is differential and conditional (Derrida 2009, 42). In taking sovereignty upon itself, the people is forced to come to terms with its historical, geographical, or cultural conditions, with its operational limitations in international and domestic environments, with its disintegration into the executive, legislative, and juridical branches, with its internal heteronomy, with its socio-political and cultural divisions - or, put simply, with its finite mortality.

In this way, the supremacy of the people runs up against the limits of how it is able to (re)present and signify itself. But the limits in which the deconstructive style of reasoning is primarily interested are not external limitations that some strands of modern political thought like classical liberalism are struggling to theorize and justify (Patton 2017, 16). In distinguishing the ahistorical abstraction of pure sovereignty from the actual constraints to the exercise of sovereignty, Paul Patton states that "[p]ure sovereignty, the sovereignty of this nation or this people, is ahistorical and indivisible, while the exercise of sovereign power is historical, conditioned and divided" (17). By setting the theorems of ahistorical abstractions up against 


\section{Krisis}

the actual constraints of practice, I think, Patton misses the aporetic limits internal to the sovereignty of the sovereign. To substantiate this claim, it is instructive to look at the determination of the omnipotent sovereign.

Whether it is envisaged as an individual or a people or even a state, the sovereign is viewed as an already constituted subject who has one voice and will; or who, as Carl Schmitt says, is entitled to decide on "the state of exception," to suspend law and rights (Derrida 2005, 153154). As a subject, the self of the sovereign presents itself as a relation closed in on itself, as an enclosed circle; but, nonetheless, there is an opening, and this "originary" opening is an opening to what disrupts from within the sovereign order of the possible or the "I can," the practice of sovereign calculations; more specifically, it is an opening to what is inconceivable and unthinkable under the given circumstances and conventional knowledge. Which means: in Derrida sovereign calculations have to calculate with the "incalculable" and the unconditioned (150-151). And, I would say, sovereignty is democratic, insofar as it is precisely nothing but this very opening to the exigency of the unconditioned or the incalculable which it is unable to master and control. As long as sovereignty has the structure of this "originary" opening, we can speak of the self-deconstruction of its traditional attributes like unconditionality and indivisibility. What defines democratic sovereignty is what it is unable to appropriate and what constantly exceeds and precedes it: that is, the exigency of the unconditioned as the announcement of a "promise." From Derrida's point of view, the promise relates to democracy.

Along with many numerous concepts, we have inherited from Ancient Greece the thing and the word "democracy" (8-9). But to be the heirs of the idea of democracy means not to receive this or that institution, this or that cultural disposition (e.g., political culture), this or that political idea (e.g., equality); instead of claiming to have immediate access to some true or authentic or original idea of democracy, one must have the courage to admit that we do not have any firm or clear clue what we have in fact inherited and are talking about. That is why it is necessary again and again to engage both actively and critically with the legacy, to reactivate the different layers of historical sedimentations, which means always doing violence by way of making a choice among multiple and contradictory sources, views, concepts, and even entire traditions (9). To be a responsible legatee means for Derrida to reaffirm and reconstruct an unconditional injunction preceding and exceeding all the theoretical, practical, normative, 


\section{Krisis}

popular discourses. Democracy, understood thus, has not yet arrived, and it will not arrive, as it is always "to come" (à venir) (86).

The open futurity of to-come refers neither to a pending future, nor to prophesy, nor to prediction, but rather to the fact that democracy is never "there" in the sense of any existing democracy, be it in the form of a constitution, regime, or government (26). Derrida conveys this excessive temporality of democracy with the neologism "democracy to come" (la démocratie à venir).

Confronted with this syntagma, it is much easier to say what the democracy to come is not than to say what exactly it is. First and foremost, we are dealing here neither with a regulative idea in the Kantian sense nor with an ideal, since both approaches to the to-come "fall, at the end of an infinite history, into the realm of the possible, of what is virtual or potential, of what is within the power of someone, some 'I can', to reach" (83-85; original emphasis). What, however, can be asserted is that the to-come of the democracy to come oscillates indecisively and parasitically between two intertwined modalities: firstly, it describes in a neutral and constative fashion what is prescribed within the word "democracy" and its inheritance (e.g., perfectibility); and, secondly, it "can also inscribe a performative attempt to win conviction by suggesting support or adherence" and, in so doing, bring into existence a democracy it declares (91). But as both proclamations presuppose the subject of enunciation, constative and performative assertions are in danger of pre-determining and thus neutralizing the temporal openness of to-come.

What escapes but also animates the constative and performative modalities of the to-come is something that Derrida calls the "promise" $(8-9,85)$. Whether we want it or not, whether we acknowledge it or not, we are caught up in the inheritance of democracy as the promise that "precedes me, swoops down upon and seizes me [...] in the form of an injunction that does not simply wait on the horizon, that I do not see coming, that never leaves me in peace and never lets me put it off until later" (84). The promise of to-come we are speaking about is born out of a withdrawal from the set of given conditions and the theological idea of history. The promise promises something that is in a singular manner heterogeneous to the order of the possible - that is, to every existing democracy (Derrida 2002, 180). It is in the structure of promises to dislocate given conditions, foundations, ideals, and rules; it overthrows the 


\section{Krisis}

pretension to make democracy conditional upon institutions, values, economic development, and even any established constitution.

In the singularity of here and now, the promise imposes itself in the form of an unconditional injunction; for example, the injunction of unconditional hospitality that reflects democracy's desire to welcome others regardless of nationality, race, faith, gender, or even better yet, to welcome whoever - or whatever - happens to come by (Derrida 2005, 41, 63). The exigency of an unconditional hospitality precedes and exceeds the actual regimes of a hospitality. Every articulation, whether performative or constative, and whether affirmative or negative, is implicitly a response to the exigency of the unconditioned, which commands to be hospitable to whomever and whatever. Hence, it is in the structure of the promise to promise the impossible. Instead of being logical and privative, without any relation whatsoever to the realm of the possible, the democratic promise for Derrida structurally requires its fulfillment - otherwise we would be speaking of a false promise or a mere promise (Derrida 2002, 26). As “democracy does not wait," it is always urgent to fulfill what is promised in the promise (see Derrida 2005, 108). When this element is lacking or downplayed, the unconditional exigency of the impossible promise is degraded to the adoration of a mere idea, a regulative idea, or an unattainable ideal. Every call of an unconditional injunction demands a prompt action, an institutionalization, and implementation. The aim of democratic politics is to strive toward the embodiment and realization of what is promised in the promise. This begins with performative or constative articulations, aiming at delimiting the specific content of the promise which, in turn, leads to shaping corresponding institutions, prescribing concrete norms, appraising specific goods, and establishing the system of laws.

Overwhelmed by the exigency of an unconditional hospitality, democrats are constantly confronted with an exigency to sovereignly formulate conditions that discriminate between those accepted as guests and those rejected as undesirable. Such acts of sovereignty decide and, in so doing, set limits to - and, in so doing, transgress - the democratic injunction of unconditional hospitality. Through the translation of the promise into action, democrats are faced with the exigency to negotiate the unnegotiable, to calculate the incalculable. The unconditional injunction of the impossible promise calls for the exigency of sovereign calculations which ends up laying down law and juridicizing the claims of justice (150). In pushing the singular 


\section{Krisis}

manifestation of the promise toward some fulfilment, I believe, democracy is outside of itself as a sovereign power.

Let us recap: If democracy is always in the process of coming, it is so not simply because of the malicious acts of sovereignty that undercut and taint the promise and therewith defer infinitely the final arrival of a "true" democracy, but because democracy will always remain in an aporetic manner dependent on sovereignty, because the exigency of a democratic promise is linked to the exigency of sovereign calculations. And, put differently, even if the sovereign power can perfectly cope without democracy, it is nonetheless an opening to something that transcends and determines it: the exigency of the promise. The conjunction of the two heterogeneous and yet inseparable exigencies is what shapes the aporia of democratic sovereignty.

\section{Autoimmune Process in Democracy and Sovereignty}

In the second essay of Rogues - "The World of the Enlightenment to Come (Exception, Calculation, and Sovereignty)" - Derrida depicts reason as living off of aporetic tensions "between, on the one hand, the exigency of sovereignty (not only but including political sovereignty, indeed state sovereignty [...]) and, on the other, the unconditional exigency of the unconditioned" (Derrida 2005, 141). The same transactions, however, are at the source of autoimmunity. In immunology, autoimmune diseases refer to a process by which an organism turns against itself and, in a suicidal fashion, destroys its own immune system. But for Derrida, the sense of autoimmunity "consists not only in harming or ruining oneself, indeed in destroying one's own protections, and in doing so oneself, committing suicide," but, and more importantly, in compromising, contaminating, and undermining the enclosed identity of the subject $(45,47-48)$. In what follows, I first examine the autoimmune processes of democracy and sovereignty, and then I relate autoimmunity to the structural openness of aporetic transactions, meaning, to the very possibility of democratic sovereignty.

In reflecting on the turmoil of the interwar years in Europe, Derrida makes the following remark: that it may happen that people decide in parliamentary elections democratically to dispose of democracy for good, e.g., preferring some other form of government. The paradigmatic case in point is fascists, who, imitating the example of Mussolini, "ascended to power through formally normal and formally democratic electoral process" (33). In similar circumstances, an alternative course of action is available: faced with anti-democratic forces, an elected 


\section{Krisis}

government itself may decide "in a sovereign fashion to suspend, at least provisionally, democracy for its own good, so as to take care of it, so as to immunize it against a much worse and very likely assault" (33; original emphasis). Under the pretext of defending democratic ideals and a way of life, a government "sends off" [renvoi] the other by, e.g., excluding the part of the demos, limiting the freedom of movement and free speech, expelling domestic and international enemies, and restricting access to the public realm; and, secondly, considering the temporal dimension, it is called "for putting off until later elections and the advent of democracy," for suspending the everyday normality of a juridico-political order, the rights and freedoms of citizens (35-37). Such measures, introduced to safeguard a democracy, corrupt the spirit of democracy "from the very outset, in an autoimmune fashion" (100). But it is not something exceptional and irrelevant in fact. For example: the more democracy wants to be hospitable, all-inclusive, and deliberative (even with its adherent enemies), the more it clears the way for its adversaries, for the perversions of democracy.

Correspondingly, Derrida expounds, sovereignty "is always in the process of positing itself by refuting itself, by denying or disavowing itself; it is always in the process of autoimmunizing itself" $(101,88)$. At stake in such a process, to repeat, is less an act of committing suicide, than "threatening the I or the self, the ego or the autos, ipseity itself" (45). This is discernible in how sovereignty is able to establish itself as self-identical only by opening itself up from within to the "other"; to engender itself as indivisible only by "inventing new distributions and forms of sharing, new divisions of sovereignty"; to immunize itself against potential diseases and foreign intruders only by unleashing the violent form of an autoimmune reaction against itself; to auto-posit itself as unscathed only by unveiling at each turn the impurity of the originary origin; to close in on itself only by promoting "an extension of the democratic beyond nationstate sovereignty, beyond citizenship" (87). This is why it is that by immunizing and mobilizing itself against heteronomy, time, alterity, and the impossible, the sovereign power runs the constant risk of committing an auto-immune suicide.

The particularities of two autoimmune processes, which emerge from the working of democracy and sovereignty, are relevant; but on the other hand, if democracy and sovereignty ought to be thought of together, I think we should explore the autoimmune vulnerability of aporetic transactions, defining the structure of democratic sovereignty. Whenever democracy is 


\section{Krisis}

exposed to sovereignty, and vice versa, there is neither only the powerless adoration of the unconditioned nor simply the machinations and stratagems of power, neither only the nonmundane, ideal order of the impossible nor simply the mundane order and art of the possible. But, at the same time, it is also true that this very same exposure of sovereign calculations to the exigency of the impossible promise (and vice versa) threatens to undermine and tear apart democratic sovereignty. Aporetic transactions are uncertain and have unanticipated outcomes. The risk is, and this risk is unsurmountable, that aporetic negotiations lead to the installations of, e.g., autocracy or a corrupt government.

Faced with the ever-present dangers, it is discernable why there is a temptation to immunize and securitize against the very openness of aporetic transactions, against the reciprocal exposure of the two exigencies. This immunization, however, strikes against the very thing that is central to the structure of democratic sovereignty. Whether the injunction of a democratic promise is closed off from, or securitized against, the acts of sovereign calculation, or whether the sovereign power seals itself off from the exigency of the promise, aporetic negotiations are blocked. Today, neoliberal rationality and right-wing populist reason illustrate in their respective ways the autoimmune self-destruction of democratic sovereignty.

\section{Autoimmune Collapse of Democratic Sovereignty in Neoliberalism and Populism}

Looking at the present situation, at least with regard to Europe, I think one cannot but notice the two conflicting trends in politics that efface in an autoimmune manner the aporia of democratic sovereignty. The first, the neoliberal mode of "governmentality," hypostasizes an existing democracy and immunizes it against popular sovereignty; and the second, right-wing populist parties, hypostasize national sovereignty and immunize it against the encounter with the impossible promise. With the following brief remarks, I show how neoliberal and populist reason immunize themselves against the openness of aporetic transactions.

The collapse of liberal democracies between the two world wars, the Great Depression, the expanding policies of political redistribution, and the success of Keynesianism provided impetus for reevaluating the basic tenets of classical liberalism. What emerged as a result of this endeavor is nowadays called "neoliberalism" (Dardot \& Laval 2013, 21-48). While classical liberalism was primaril concerned with restricting the power of the state in favor of individual 


\section{Krisis}

liberties and free enterprise, the proponents of neoliberalism manipulate the resources of the state-apparatus to construct and sustain a set of juridical rules and morals necessary for the smooth workings of the economy (30-32). A free market economy, it is believed, is dependent on a host of non-economic factors, such as morals and law. In its recent policies, such as privatization, deregulation, and austerity, the issue at stake is that of how to govern society and the state most cost-efficiently. The strategic aim of this governmentality is to extend an entrepreneurial mentality to all domains of life, including public services such as health-care and education.

What is characteristic of the doctrines of neoliberalism is a refusal "to identify democracy with 'popular sovereignty,' understood not as the direct exercise of legislative power by the people, but as the promotion of the will of the people to the rank of the sole source of legitimacy for the rulers' activity" (Dardot \& Laval 2019, 32). For instance, this reluctance is visible in how neoliberals are suspicious of popular participation, either because it may disturb the logic of the market or because it threatens to violate individual liberties. Hence, it makes perfect sense to speak about the economic liberties of individuals and, concomitantly, to be suspicious about the demands of social rights and the political freedom of a people. The role of citizens is confined to choosing leaders, the best managers available on the market. The depletion of popular sovereignty empties democracy of its substance (Dardot \& Laval 2013, 306-307; Brown 2015).

Similarly, Derrida lauds in Rogues as in his other writings how the self-deconstruction of sovereignty "is already under way. It is at work today; it is what's coming, what's happening" (Derrida 2005, 157; original emphasis). In light of that, it may look as though Derrida's position is in line, and probably to some extent even complicit, with neoliberal efforts to domesticate and disable popular sovereignty in liberal democracies. But if we take into account the promise of the to-come, I think fundamental disagreements come into view.

Most importantly, when combating popular sovereignty head-on, neoliberal rationality aims to ascertain what is optimally possible and imaginable in accordance with the logic of the market. In the place of the people, the market is now posed as a benevolent sovereign, which functions as a source of disciplining and pacifying the emotions and wishes of the public and politicians. Having accepted this framework, mainstream parties in Europe have nothing left over but to advocate the "right" type of policies, by means of which to manage and regulate 


\section{Krisis}

socioeconomic relations. Rather than adjusting itself every day to the singular appearance and renewal of the promise, a market-oriented democracy is at pains to regulate and adjust itself every day in accordance with the trends or fluctuations of markets. Having lost enthusiasm for the impossible, the givens of an existing democracy are hypostatized and immunized against the claims of popular sovereignty.

As a reaction, or as an accompaniment, to a managerial predicament, we are now observing the rise of right-wing and left-wing populist parties across Europe and beyond. In contrast to major ideologies like liberalism and socialism, the term "populism" cannot be reduced to a fixed set of ideas or policies. Depending on the situation, populism may acquire a wide variety and even contradictory contents, ranging from left-wing (e.g., Podemos in Spain) to right-wing populism (e.g., the National Rally in France), from the democratic (e.g., the Syriza in Greece) to the authoritarian (e.g., the Fides in Hungary). What are more or less common to such heterogeneous diversity are features "such as the invocation of the people, the split between people and elites, the demand for participation, the centrality of strong leaders or the cavalier attitude towards institutional procedures" (Arditi 2008, 86). The desire to empower and give a voice to the "common people," the "moral majority" against the "corrupt" and "hypocritical" elite, may positively affect a political system, but in the long run, populism presents "a real danger to democracy" (Müller 2016, 82). One source of danger consists in how surging populist parties in Europe tend to reassert a claim of popular sovereignty.

From the Austrian Freedom Party to the Finns Party and beyond, radical-right populists, but not exclusively, appeal to the urgency of responding to, say, "the problems of immigration," "the decay of Christian values," "the exploitation of big corporations," "the deficit of democratic legitimacy," and "the corruption of the liberal elite." No matter how the contours of the crisis happen to be diagnosed, however, it all comes down to acting promptly - and decisively. To empower the people so that they can decide their own fate, populist parties claim the need of wresting back control of sovereignty from international institutions, liberal globalists, corrupt elites, minorities, and outsiders. To decide autonomously on the nature of its own borders, institutions, identity, and values, means to reassert the indivisible and unconditional sovereignty of the nation-state. Drawing on the previous exploration of Derrida's views, I would claim that national sovereignty elevates what is divided and mortal and conditional into the 


\section{Krisis}

status of the unconditioned. The nation is hypostatized, meaning it is an existing, constituted subject that stands at the source of an ultimate decision. The final say of the people is cordoned off from the exigency of what disrupts the order of the possible in the form of a promise.

In that respect, populist reason is antithetical to neoliberal rationality. Regardless of disagreements, however, both lines of thinking domesticate aporetic tensions within democratic sovereignty. Whether democracy is leveled out to the host of conditionalities and immunized against claims to popular sovereignty, or alternatively, whether national sovereignty is elevated to the rank of unconditionality and immunized against the impossible promise, the endresult is similar in that both produce the closure of a play between what sovereign calculations consider possible and the exigency of a democratic promise. In setting out to save democracy, the neoliberal imagination of pure democracy without popular sovereignty, and the populist imagination of national sovereignty without the exigency of the promise, result in the autoimmune self-betrayal of democratic sovereignty. For, in making an existing democracy safe and sound against the supposed ills and dangers of political sovereignty, neoliberals actually betray nothing but democracy itself; or, conversely, in making national sovereignty safe and sound against the encounter with the impossible, populists actually undercut nothing but sovereignty itself (Derrida 2005, 35, 45, 101; cf., Brown 2009, 120). The neoliberal and populist ways of immunization are thus the ways of autoimmunization: both yield to the autoimmune self-betrayal of democratic sovereignty. This very kind of vulnerability, however, proves the untenability and shallowness of pure democracy and a self-enclosed sovereignty. That is why autoimmunity is the condition of (im)possibility for the aporia of democratic sovereignty.

While the logics of neoliberalism and populism mark the perverse inner margins of democratic sovereignty, the greater challenge we face today comes from those political forces that seek to undo and probably go beyond the process of aporetic transactions. This challenge which presents itself in the form neoliberal populism raises the question as to what it means to endure the aporia of democratic sovereignty.

\section{Enduring the Aporia of Democratic Sovereignty}

In her For a Left Populism (2019), Chantal Mouffe argues that the rise of populist parties is caused by the crisis of neoliberal hegemony. Neoliberal rationality eradicates a left-right opposition in favor of a consensus at the center (Blair, Schröder) and disarticulates the democratic 


\section{Krisis}

principles of popular sovereignty and equality from the liberal principles of individual liberties and the rule of law. The domestications of democracy and political struggle fuel the rise of populist parties. Polemicizing with Mouffe's diagnosis, Didier Fassin responds in his "The Blind Spots of Left Populism" that there is no crisis of neoliberal hegemony. The election of Donald Trump as President of the United States proves the contrary: "Trump is an electoral victory for populism but a political victory for neoliberalism," for his win "allows his political allies and rich donors to discreetly get their neoliberal agenda through" (Fassin 2019, 88-89; cf., Dardot \& Laval 2019, xi-xxix). Thriving on obscene rhetoric, Trumpism displays a transformation and radicalization of neoliberal strategy to secure "tax cuts for corporations and the wealthy, budget reductions for social and health programs, deregulation of finance, consumer protection and environmental preservation" (Fassin 2019, 89). What neoliberal populism reveals in its diverse stripes like Macronism is an emerging alliance of liberal entrepreneurism and national sovereignty.

Looking at the present situation, the key question to ask is how Trumpism relates to the aporia of democratic sovereignty. To respond to this problem I highlight some of the infrastructural features of aporia: the recurring urgency to engage in aporetic transactions, the moment of undecidability, the unavoidability of risks, and the absence of an already established subject.

Firstly, what is at issue in the living spirit of democratic sovereignty is the subversive interplay between the exigency of democratic promise and that of sovereign calculations. The heterogeneity of both exigencies "does not exclude but, on the contrary calls for their inseparability" (Derrida 2005, 150). In the singular exigency of hic et nunc, it is always urgent to negotiate between what appears to be impossible (e.g., the democratic injunction of a limitless hospitality) and what is possible (e.g., the sovereign determination of the limits). In every moment as in every place, there is ever-present pressure to enter into aporetic negotiations. This pressure is what seizes democrats each time and each place anew.

Secondly, the relationship between the need of sovereign calculations and the injunction of the incalculable promise is radically "undecided" (150). Between the exigency of the incalculable and that of the calculable, the impossible and the possible, there is an element of undecidability; which means: the process of aporetic negotiations is "without any rule given in advance, without any absolute assurance," without any fixed model and established guidelines. That is 


\section{Krisis}

why it is not predetermined what will happen when democracy resorts to the use of power in order to protect itself and fight its enemies. The irreducibility of undecidability signals the structural openness of aporetic negotiations.

Thirdly, the promise is a promise only if "there is a threat in the promise itself," a threat in every response to the promise ( 82 , original emphasis). The threat, it is significant to add, is inseparable from the opportunity: It is an opportunity, inasmuch as it makes possible the "progressive" revisions of every existing democracy in deconstructing oppressive hierarchies, power-relations; and, on the other hand, it is the threat, inasmuch as it threatens to result in tyranny, anarchy, oligarchy, or the retreat of democracy (Derrida 2002, 31). The processes of aporetic negotiations carry autoimmune risks. Without risks, there would be no aporetic transactions at the hearth of democratic sovereignty.

Fourthly, contrary to what may be supposed, it is not a subject - an individual, a collective, or a state - that pulls all the strings behind the scene and decides on the undecidable, determining in advance the course of aporetic transactions. Rather than controlling and directing negotiations, the subject arises "from the standpoint of an affirmation it does not control. The affirmation is before me. I am not the one who affirms"; which means: The sovereignty of the "I can" is not at the source of a decision, but rather the effect of negotiations (27). The chiasm between the two heterogeneous but inseparable exigencies is what gives birth to the moment of a sovereign decision.

The here-and-now exigency of aporetic transactions, the unavoidability of risk, the moment of undecidability, and the absence of a constituted subject, point to the fact that the aporetic limits of democratic sovereignty are not objectively given. Any place, any time, it is necessary to engage in the process of negotiating and re-negotiating what are the contours of democratic sovereignty. Aporetic negotiations go on, as long as the limits of democratic sovereignty are not made completely intelligible, for example, either ossified in the adoration of the ideally possible, or subjected to the sovereign management and administration of the possible.

But if one is after circumscribing and rendering visible the aporicity of aporia, aporia cancels itself out. This is the main conclusion Derrida reaches in discussing Heidegger's phenomenological analysis of death as "the possibility of impossibility." "The ultimate aporia," Derrida 


\section{Krisis}

Krisis 2021, issue 1

recaps against Heidegger, "is the impossibility of the aporia as such" (Derrida 1993, 78; original emphasis). What makes possible the appearance of aporia makes simultaneously impossible the "as such" of aporia. The appearing of the "as such" neutralizes the moment of undecidabiltiy, the moment of risk, the urgency of hic et nunc or, simply put, the process of aporetic transactions between the conditional and the unconditioned. The "as such," whether phenomenological, ontological, or epistemological, annuls the possible-impossible, calculable-incalculable tensions internal to the experience of aporia (e.g., Derrida 2005, 144). Reckoning with the aporia of democratic sovereignty requires reckoning with the impossibility of aporia ever appearing as such. The aporetic limits of democratic sovereignty are unintelligible and indeterminable.

With this in mind, we may go back to the question posed at the beginning of this section: How does Trumpism relate to the aporia of democratic sovereignty? To give a concise response, I venture to speculate and put forward a hypothesis that the election of Trump testifies to an effort to reconcile what is irreconcilable: decisiveness with super-legalism (the exclusion of the exception), the suspension of law (the waning of the Rechtsstaat) with the rule of law/order (the universalization of economic norms), the traditional attributes of sovereignty with the rule of markets, the will of the people with majority rule. Considered thus, the person of Trump embodies the impossible unity of democracy and sovereignty, meaning that he embodies an effort to master and control the aporetic limits of democratic sovereignty as such. The neoliberal populism of Trump annuls the aporia of democratic sovereignty.

\section{References}

Agamben, Giorgio. 1998. Homo Sacer: Sovereign Power and Bare Life. Stanford: Stanford University Press.

Arditi, Benjamin. 2007. Politics on the Edges of Liberalism: Difference, Populism, Revolution. Edinburgh: Edinburgh University Press.

Brown, Wendy. 2009. "Sovereign Hesitations." In Cheah, Pheng \& Guerlac, Suzanne. (eds.) Derrida and the Time of the Political. Durham: Duke University Press, 114-134.

Brown, Wendy. 2015. Undoing the Demos: Neoliberalism's Stealth Revolution. New York: Zone Books.

Caputo, John. "Without Sovereignty, Without Being: Unconditionality, the Coming God and Derrida's Democracy to Come." France Today 4, No. 3 (August 2003).

Dardot, Pierre \& Laval, Christian. 2017. The New Way of the World: On Neoliberal Society. London: Verso.

Dardot, Pierre \& Laval, Christian. 2019. Never Ending Nightmare: The Neoliberal Assault on Democracy. London: Verso.

Derrida, Jacques. 1993. Aporias. Stanford: Stanford University Press. 
Derrida, Jacques. 2002. Negotiations: Interventions and Interviews, 1971-2001. Stanford: Stanford University Press.

Derrida, Jacques. 2005. Rogues: Two Essays on Reason. Stanford: Stanford University Press.

Derrida, Jacques. 2009. The Beast \& the Sovereign, Vol. 1. Chicago: University of Chicago Press.

Fassin, Didier. 2019. "The Blind Spots of Left Populism.” Krisis: Journal for Contemporary Philosophy, No. 1: 86-90.

Fritsch, Matthias. 2002. "Derrida's Democracy to Come." Constellations: An International Journal of Critical and Democratic Theory 9 (4): 574-597.

Haddad, Samir. 2013. Derrida and the Inheritance of Democracy. Bloomington: Indiana University Press.

Mansfield, Nick. 2010. The God Who Deconstructs Himself: Sovereignty and Subjectivity between Freud, Bataille, and Derrida. New York: Fordham University Press.

Mouffe, Chantal. 2019. For a Left Populism. London: Verso.

Müller, Jan-Werner. 2016. What Is Populism? Pennsylvania: University of Pennsylvania Press.

Nancy, Jean-Luc. 2000. "War, Right, Sovereignty-Techne.” In Nancy, Jean-Luc, Being Singular Plural. Stanford: Stanford University Press.

Patton, Paul. 2017. "Deconstruction and the Problem of Sovereignty." Derrida Today 10 (1): 1-20.

Thomson, Alex. 2007. Deconstruction and Democracy: Derrida's Politics of Friendship. London: Continuum.

Thomson, Alex. 2015. "Democracy and Sovereignty." In Colebrook, Claire. (ed.) Jacques Derrida: Key Concepts. Durham: Acumen Publishing Ltd.

Vardoulakis, Dimitris. 2018. Stasis before State: Nine Theses on Agonistic Democracy. New York: Fordham University Press.

\section{Biography}

Janar Mihkelsaar is an early career fellow with experience in conducting research in the fields of continental philosophy, political philosophy and political science. He was a KONE research fellow at the University of Jyväskylä. This research was supported by the KONE Foundation. 